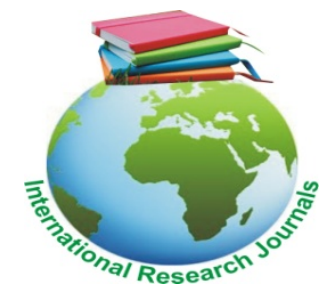

African Journal of Food Science and Technology (ISSN: 2141-5455) Vol. 6(5) pp. 136-140, August, 2015

Available online @http://www.interesjournals.org/AJFST

DOI: http:/dx.doi.org/10.14303/ajfst.2015.052

Copyright @2015 International Research Journals

Full Length Research Paper

\title{
Physicochemical and sensory evaluation of soy/carrot drinks flavoured with beetroot
}

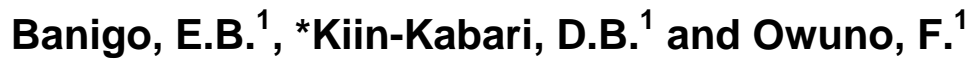 \\ ${ }^{1}$ Department of Food Science and Technology, Rivers State University of Science and Technology, Port Harcourt, \\ Rivers State, Nigeria. \\ *Corresponding Author's email: kabaridavid@yahoo.com
}

\begin{abstract}
Soy/Carrot/Beetroot drinks were prepared with various ratios of the different vegetables. The Physicochemical properties, sensory evaluation of the drinks were evaluated. Physicochemical parameters of the drinks showed the drinks were almost at neutral $\mathrm{pH}$ as the values ranged from 5.95 in sample $F$ to 6.42 in sample $E$. Values for sugar (Brix\%) ranged from $8.00-9.00$, total solid (\%) ranged from 8.07 in sample $F$ to 10.70 in sample $E$. Values for viscosity ranged from 0.331 pa.s in sample $C$ to 0.415 pa.s in sample E. Proximate composition of the drinks showed values for moisture content ranging from $\mathbf{8 9 . 3 1 \%}$ in sample $E$ to $\mathbf{9 2 . 1 0 \%}$ in sample C. Results for total ash fall between $0.39 \%$ in sample D to $0.53 \%$ in sample E. Sample E and $F$ with the highest amount of soymilk and carrot drink, respectively gave the highest value for ash. Results for protein content ranged from $0.03 \%$ (sample F) to $0.53 \%$ in sample $E$, showing an increase with the increase in the soy content of the drinks. Values for carbohydrate ranged from $2.48 \%$ in sample $A$ to $4.96 \%$ in sample $E$. The fat content of the drinks were generally low but showed an increase with increase in the soy content of the drinks. Sensory results showed the drinks were acceptable to the panelist as indicated by the average score of 5.9. Sample E (with $90 \%$ soymilk and $10 \%$ Beetroot juice was the most preferred for overall acceptability.
\end{abstract}

Keyword: Soymilk, carrot juice, beetroot, vegetable drink, fruit drinks.

\section{INTRODUCTION}

All over the world, health concerns have led to the popularization of natural drinks as a healthy alternative to other beverages.Fruit drinks and juices are nutritious, have a great taste and health benefits (Suad and Eman, 2008). Non alcoholic beverages, especially fruit drinks play a vital role in the diets of people in both developed and developing countries. They are regarded as after meal drinks or refreshing drinks during the dry season in rural and urban centres (Babajide et al, 2013). Fruits and drinks are consumed for their characteristic aroma and also considered a source of soluble and insoluble fibres, vitamins and minerals (Righetto et al., 1999).

A number of fruits, vegetables and in some cases soybean have become useful raw materials in the production of natural drinks. Production and preservation ofcashew-apple juice for use at off-season as an alternative to foreign juice and natural drink with high vitamin C content (Emelike and Ebere, 2015). Soymilk, an aqueous, white and creamy extract produced from soybeans which resembles cow milk both in appearance and consistency is a highly nutritious food drink which contains protein, fat, carbohydrate, vitamins and minerals. (Maduekwe et al., 2013).

Carrots according to Bazilla et al., (2012) is a rich source of $\beta$ - Carotene and vitamins like thiamine, riboflavin, vitamin B-complex and minerals.Carrot drinks have been used as a healthy drink in homes in Nigeria. The consumption of carrots and its related products has increased steadily due to the recognition of its antioxidant and anti-cancer activities of $\beta$-Carotene in carrot which is also a precursor of vitamin A (Mridula, 2011). The vitamins in carrot juice helps to promote growth for visual light and colour, preventing dryness of skin and eyes (Ochulor et al., 2013). 
Beetroots are rich sources of potent antioxidants and nutrients. It is an excellent source of foliate, manganese and iron (Wiki, 2013) and can complement soymilk and carrot juice in these areas. Beetroot has already been established as a flavouring agent or a special flavour that is generally liked by people who have known its benefits and functions (Mbaeyi-Nwaoha and Nwachukwu, 2012). Stephen (2014) also reported that Beetroot is used commercially as a food dye in ice cream, sweets, yoghurt and other confectionaries. Beetroot is a rich source of dietary inorganic nitrate and a number of studies have investigated its potential for reducing blood pressure in humans (Webb et al, 2008; Bailey et al., 2009; Vanhatalo et al., 2010). Coles and clifton (2012) reported that after consumption to beetroot juice on a low nitrate diet may lower blood pressure and therefore reduce the risk of cardiovascular event.

In Nigeria today, there is a preponderance of milk drinks with a strong fruit content, that is often beyond the reach of the less endowed in the society. Encouraging the home stead production of milk drinks while harnessing the nutritional and flavour properties of soybean, carrot and beetroot will no doubt enhance the nutrient intake of the less privileged, as these raw materials are available. Also the combination of these vegetables will make a highly nutritious and health supporting drink for human consumption. Based on the nutrient dense properties of these vegetables, the study is aimed at developing health drink from soymilk and carrot flavoured with beetroot juice. To evaluate the Physicochemical and sensory properties of the developed drinks in order to ascertain its acceptability.

\section{MATERIALS AND METHODS}

\section{MATERIALS}

Soybean (gycine max), carrot (Daucuscarota), Beetroot (Beta vulgaris) and sugar were purchased from Mile three market in Port Harcourt, Rivers State, Nigeria. The vegetables were sorted and cleaned so as to remove dirts and spoilt ones, thoroughly washed before processing.

\section{METHODS}

\section{Sample Preparation}

The soybeans were sorted to obtain clean white seeds, soaked in a volume of water four times its weight at $260 \mathrm{C}$ and $750 \mathrm{C}$ for $16 \mathrm{~h}$. The beans were manually dehulled, washed and allowed to drain. The carrot and beetroot were washed and the skin scraped off, washed again and sliced.

\section{Preparation of soy/carrot/Beetroot Drink (SCBD)}

A modified Carrao (1999) method was used. $380 \mathrm{~g}$ of the dehulled soy bean was weighed and blended using a Philips HR2000 blender for 5 min. The milk was extracted by sieving the paste with a muslin cloth and water was added in the milk to water ratio of 1:10. The milk was heated at $95^{\circ} \mathrm{C}$ for $15 \mathrm{~min}$ and cooled.

A $204 \mathrm{~g}$ of beetroot or carrot was weighed with a digital electronic balance. They were cut into slices of about $2-3 \mathrm{~mm}$ thick and subjected to extraction using a juice extractor (Iloytron 23438. UK). The pulp obtained was sieved with muslin cloth using a pulp to water ratio of 1:4 to obtain beet juice or carrot juice. The soymilk carrot drinks flavoured with beetroot juice were prepared according to the formulation shown in Table 1. The mixture was homogenized using a high speed homogenizer and transferred into bottles previously washed with hot water, stoppered and pasteurized at $750 \mathrm{C}$ for $15 \mathrm{~min}$ using a water bath (Techno test, Italy) and thereafter allowed to cool to room temperature.

\section{Physicochemical Properties}

Viscosity: The viscosity of the drinks was determined with the aid of a Rotary digital viscometer (NDJ.8S, China) using spindle number 2 at $12 \mathrm{rpm}$. $250 \mathrm{~m} 1$ of the drink was transferred into a $250 \mathrm{~m} 1$ beaker. The content of the beaker was introduced directly unto the rotating spindle and the value of the viscosity displayed on the LCD screen in pa.S was recorded.

$\mathrm{pH}$ : The $\mathrm{pH}$ of the drinks was determined using a $\mathrm{pH}$ meter (TS 625, USA). Twenty (20ml) of the drink was transferred into a beaker and the $\mathrm{pH}$ was determined after the meter was calibrated using standard buffer of $\mathrm{pH}$ 4.0 and 7.0, sufficient time was allowed for stabilization before readings were taken.

Sugar: The hand held sugar refractometer was used. The prism of the refractometer was cleaned and a drop of the drink was placed on the prism and closed. The sugar content percentage (soluble sugar) was read from the scale of the refractometer when held close to the eye.

Proximate composition: The moisture content, total solid, ash and crude protein were determined by the method of AOAC (2012). Fat was determined by RoseGottlieb method (Pearson, 1981) while manual cleggAnthrone method (Osborne and Voogt, 1978) was used in the determination of total available carbohydrate.

Sensory evaluation: The sensory analysis was carried out using a twenty member panelist consisting of staff and students of Food Science and Technology Department, Rivers State University of Science and Technology, Port Harcourt, Rivers State Nigeria. The organoleptic qualities evaluated were: Taste, Colour Mouth feel, Flavour and Overall acceptability. The prepared drinks were served with clean glasses to 
Table 1: Formulation of Soy-Carrot-Beetroot Drink

\begin{tabular}{llll}
\hline Sample & Soymilk(m1) & Carrot Juice $(\mathbf{m l})$ & Beetroot Juice $(\mathbf{m} \mathbf{)})$ \\
\hline A & 800 & 100 & 100 \\
B & 700 & 200 & 100 \\
C & 600 & 300 & 100 \\
D & 500 & 400 & 100 \\
E & 900 & 0 & 100 \\
F & 0 & 900 & 100 \\
\hline
\end{tabular}

Key:A = Soy/Carrot/Beetroot (ratio 80:10:10), B = (ratio 70:20:10), C = (ratio 60:40:10), D = (ratio 50:40:10), E = (ratio 90:0:10), $F=($ ratio 0:90:10)

Table 2. Physical Properties

\begin{tabular}{|c|c|c|c|c|c|}
\hline Sample & $\mathrm{pH}$ & $\begin{array}{l}\text { (Soluble) } \\
\text { Sugar (\%) }\end{array}$ & Solids & Total Solid (\%) & Viscosity (Pa.S) \\
\hline$A$ & $6.11^{a}$ & $9.00^{a}$ & & $9.34^{a}$ & $0.391^{a}$ \\
\hline $\begin{array}{l}B \\
C \\
D \\
E \\
F\end{array}$ & $\begin{array}{l}6.33^{\mathrm{a}} \\
6.36^{\mathrm{a}} \\
6.34^{\mathrm{a}} \\
6.42^{\mathrm{a}} \\
5.92^{\mathrm{a}}\end{array}$ & $\begin{array}{l}8.14^{\mathrm{a}} \\
9.00^{\mathrm{a}} \\
9.00^{\mathrm{a}} \\
9.00^{\mathrm{a}} \\
8.00^{\mathrm{a}}\end{array}$ & & $\begin{array}{l}8.50^{a} \\
9.24^{a} \\
9.91^{a} \\
9.40^{a} \\
8.17^{a}\end{array}$ & $\begin{array}{l}0.395^{b} \\
0.331^{b} \\
0.361^{b} \\
0.415^{b} \\
0.372^{b}\end{array}$ \\
\hline
\end{tabular}

Results shows means \pm SD of duplicate readings. Values with different superscript in the same column are significantly different $(p \leq$ 0.05)

Key:A = Soy/Carrot/Beetroot (ratio 80:10:10), $B=($ ratio 70:20:10), $C=($ ratio 60:40:10), $D=($ ratio 50:40:10), $E=($ ratio $90: 0: 10), F=($ ratio 0:90:10)

Table 3. Proximate Composition and Energy

\begin{tabular}{lllllll}
\hline Sample & $\begin{array}{l}\text { Moisture } \\
\text { Content (\%) }\end{array}$ & Ash (\%) & Fat (\%) & $\begin{array}{l}\text { Crude } \\
\text { Protein (\%) }\end{array}$ & $\begin{array}{l}\text { Total } \\
\text { Carbohydrate } \\
\text { (\%) }\end{array}$ & $\begin{array}{l}\text { A. } \\
\text { Energy } \\
\text { (Kcal/100ml) }\end{array}$ \\
\hline A & $90.66 \pm 0.72$ & $0.40 \pm 0.03$ & $1.38 \pm 0.14$ & $0.27 \pm 0.09$ & $2.48 \pm 0.16$ & 21.35 \\
B & $91.87 \pm 0.23$ & $0.42 \pm 0.07$ & $1.18 \pm 0.03$ & $0.29 \pm 0.90$ & $3.14 \pm 0.24$ & 24.16 \\
C & $92.10 \pm 0.03$ & $0.43 \pm 0.12$ & $1.16 \pm 0.01$ & $0.23 \pm 0.04$ & $3.06 \pm 0.13$ & 23.60 \\
D & $91.93 \pm 0.06$ & $0.39 \pm 0.01$ & $1.09 \pm 0.11$ & $0.21 \pm 0.09$ & $3.58 \pm 0.04$ & 24.97 \\
E & $89.31 \pm 0.72$ & $0.53 \pm 0.19$ & $1.56 \pm 0.01$ & $0.53 \pm 0.07$ & $3.49 \pm 0.06$ & 30.12 \\
F & $91.53 \pm 0.00$ & $0.46 \pm 0.06$ & $0.89 \pm 0.04$ & $0.03 \pm 0.01$ & $4.91 \pm 0.09$ & 27.77 \\
\hline
\end{tabular}

Key: $A=$ Soy/Carrot/Beetroot (ratio 80:10:10), $B=($ ratio 70:20:10), $C=($ ratio 60:40:10), $D=($ ratio 50:40:10), E = (ratio 90:0:10), F = (ratio 0:90:10)

individual panelist. The order of presentation of samples to the panel was randomized, portable water was provided to rinse the mouth between evaluations. Each sensory attribute was on a 9 - point Hedonic Scale with 1 = disliked extremely while $9=$ liked extremely as reputed by Iwe (2010)

Statistical analysis: The method of Wahua (1999) was used to analysis the data using analysis of variance (ANOVA). The sensory evaluation were subjected to oneway analysis of variances, all means were separated using Duncan Multiple Range test and least significant difference at $5 \%$ probability level $(p>0.05)$ using SPSS version 20.0 software 2011.

\section{RESULTS AND DISCUSSION}

\section{Physico-chemical Properties}

The results of the physio-chemical properties of the drinks are shown in Table 2. The value for $\mathrm{pH}$ ranged from 5.92 in sample $F$ to 6.42 in sample $E$. The values for $\mathrm{pH}$ shows the drinks were almost at a neutral $\mathrm{pH}$. These values were however less acidic when compared with 4.36 - 4.41 reported by Babajide et al., (2013) for spiced cucumber and pineapple drinks. This difference may be due to the $\mathrm{pH}$ of pineapple. Values for soluble sugar ranged from $8.00-9.00 \%$. Sample F without soymilk 
Table 4. Mean Sensory Scores of Soy/Carrot/Beetroot Drinks

\begin{tabular}{|c|c|c|c|c|c|}
\hline Sample & Colour & Taste & Flavour & Mouthfeel & $\begin{array}{l}\text { Overall } \\
\text { acceptability }\end{array}$ \\
\hline$A$ & $7.65^{a}$ & $6.35^{\mathrm{a}}$ & $6.35^{\mathrm{a}}$ & $6.65^{b}$ & $6.95^{b}$ \\
\hline B & $7.45^{\mathrm{a}}$ & $5.95^{d}$ & $6.05^{b}$ & $6.55^{b}$ & $6.85^{b}$ \\
\hline C & $7.00^{b}$ & $6.50^{\mathrm{C}}$ & $6.05^{b}$ & $6.05^{\mathrm{b}}$ & $6.55^{c}$ \\
\hline$D$ & $7.15^{\mathrm{b}}$ & $6.65^{\mathrm{C}}$ & $6.70^{a}$ & $6.40^{b}$ & $6.90^{b}$ \\
\hline E & $7.60^{\mathrm{a}}$ & $7.75^{a}$ & $7.05^{a}$ & $7.25^{\mathrm{a}}$ & $7.80^{\mathrm{a}}$ \\
\hline $\mathrm{F}$ & $7.65^{a}$ & $7.05^{b}$ & $6.80^{a}$ & $6.75^{b}$ & $7.10^{b}$ \\
\hline
\end{tabular}

Results shows means \pm SD of duplicate readings. Values with different superscript in the same column are significantly different $(p \leq 0.05)$

Key: $\mathrm{A}=$ Soy/Carrot/Beetroot (ratio 80:10:10), $B=($ ratio 70:20:10), $C=($ ratio 60:40:10), $D=($ ratio 50:40:10), $E=($ ratio 90:0:10), $F=($ ratio 0:90:10).

gave the least value. The generally low sugar content will make the drinks suitable as a low calorie drink. Results for total solids showed sample $E$ with the highest amount of soymilk gave the highest value, followed by sample $D$, it was also observed that the differences between sample $E$ and $A, E$ and $C$ were not significant. The results for total solids thus showed an increase with increase in soymilk content of the drinks. The result for total solids in sample $E$ also correlates with the value for viscosity as it also recorded the highest value of 0.415 pa.S.

\section{Proximate composition}

The result for proximate composition is presented in Table 3. Values for moisture content ranged from $89.31 \%$ in sample $\mathrm{E}$ to $92.10 \%$ in sample C. These values agreed with the report of Hiroya et al., (1992) who reported $80 \%$ moisture content for skimmed sweet yoghurt and a range of $60-90.8 \%$ reported by MbaeyiNwaoho and Nwachukwu (2012) for yoghurt flavoured with beetroot.Drinking juice is one of the ways of taking water which is vital for the transportation of food and waste, digestion and the regulation of body temperature. Results for ash ranged from $0.39 \%$ in sample D to $0.53 \%$ in sample E. Values for ash was highest in sample $\mathrm{E}$ $(0.53 \%)$, followed by sample $F(0.46 \%)$, sample $E$ which contains $90 \%$ soymilk and sample $\mathrm{F}$ with $90 \%$ carrot drink both gave the highest values of ash $(0.53 \%$ and $0.46 \%$ ),respectively. Suad and Emen (2008) reported that fruit drinks are important sources of minerals. Result of crude protein showed a decrease in pruting and in protein content with increase in the amount of carrot juice in the drinks. Sample F without soymilk gave the least value for crude protein $(0.03 \%)$. The carbohydrate content of the drinks showed an increase with increase in the carrot component from sample $A$ to $D$, the highest value for carbohydrate was in sample $F$ with the $90 \%$ carrot content. The fat content result increased with increase in the soymilk content of the drinks. The fat content of the drinks were generally low. Fruit juices and drinks are not good sources of fat. Values for energy ranged from $21.35 \mathrm{Kcal} / 100 \mathrm{ml}$ in sample $A$ to 30.12 $\mathrm{kcal} / 100 \mathrm{ml}$ for sample E. Sample with the highest amount of soymilk in the drinks gave the highest value and this was followed with sample $E$ with the highest amount of carrot content in this drinks. Values for A, B, C, and D were close.

\section{Sensory evaluation}

Results for sensory evaluation are as shown in Table 4. The result showed sample $A, B, E$ and $F$ were the most preferred for colour and values were significantly different from $C$ and D. Sample $F$ had the least preference for colour. Sample $\mathrm{E}$ with the highest amount of soymilk was the most rated for taste by the panelist followed by sample $F$ with the highest amount of carrot. Sample B had the least preference for taste. Sample D and E were the most preferred for flavor while sample $E$ had the highest preference for mouth feel and overall acceptability. The sensory results showed the products were acceptable to the panelists as seen in the average score of above 5.9.

\section{CONCLUSION}

A refreshing fruit drink was produced from soymilk and carrot juice flavoured with $10 \%$ beetroot juice. Sample E with $90 \%$ soymilk and no carrot was preferred for flavour, colour, mouthfeel, taste and overall acceptability. However, production of carrot juice flavoured with beetroot juice should be further investigated and the storage stability of the drinks determined.

\section{REFERENCES}

AOAC (2012). Official methods of analysis of the association of official analytical chemists, 20thed.

Babajide JM, Olaluwoye AA, TaofikShittu TA, Adebisi MA (2013). Physico-chemical properties and phytochemical components of spiced cucumber - Pineapple Fruit Drink. NIFOJ 31:40-52.

Bailey SJ, Winyard P, Vanliatalo A, Blackwell JR, Dimenga FJ, Wilkerson DP, Benjamin N, Jones AM (2009). Dietary nitrate supplementation reduces the 02 cost of low - intensity exercise and enhances tolerance to high-integrity exercise in humans. J. Physiology. 107, $1144-1155$. 
Brazila Gayas, Rama Ns, Beene MK (2012). Phyaico-chemical and sensory characteristics of carrot pomace powder enriched defatted soyflour fortified biscuits International journal of scientist and research publications 2(8), 1-5.

CarraoPanizzi MC, Adelaide DB, Ferreira SHP, Oliveira MCN, Kitamura K (1992).Effects of Isoflavones on beany flavour and astringency of soymilk and cooked whole soybean grains .Pesyuisa Agro pecuaria Brasileira, 34:6.

Coles ZI, Clifton PM (2012). Effect of Beetroot juice on lowering blood pressure in free-living, disease-free adults: a randomized, placebocontrolled trial. Nutrition J.11, 106. Dio:10.1186/1475.

Emelike NJT, Ebere CO (2015). Effect of packaging materials, storage conditions on the vitamin $\mathrm{C}$ and $\mathrm{pH}$ value of cashew-apple (Anacardium occidentale L.) juice.Journal of Food and Nutrition Sciences. 3(4), 160-165. Doi:10.11648/j.jfns.20150304.14.

Harold E, Ronald SK, Ronali S (1981). Pearson's Chemical Analysis of Foods, 8th ed. Churchill Livingstone. New York: P 23, 229-232.

Hiroya Y, Isuotmu G, Shige OO (1992). The nutritional and physiological value of fermented milks, in: function of fermented milk, challenges for the Health Science, Elsevier Applied Science Publishers, London, $345-567$.

Iwe MO (2010). Handbook of Sensory methods and analysis, 75-78. Enugu Nigeria Rejoint Communication Science Ltd.

Maduekwe EU, Eme PE, Okpara CE (2013). Nutrient content and microbial quality of soymilk-carrot powder blend. Pakistan J. of Nutrition. 12(2); 158-161.

Mbaeyi-Nwaoha IF, Nwachukwu GO (2012). Production and evaluation of yoghurt flavoured with beetroot. J.of Food Science and Engineering. 2:583-592.

Mridula D (2011). Physieo-chemical and sensory characteristics of Beta carotene rich defatted soy fortified biscuits. African .J. of Food Sc., 5:305-3 12 .
Ochulor DO, Duru PC, Marthina JC (2013). The shelflife study of carrot juice using different preservative\& Conference proceedings, 37th NIFST conference. Pp. 148-149.

Osborne DR, Voogt P (1978). The analyses of nutrients in foods.Academic publishers (NC) Ltd. London.

Righetto AMA, Beeia SHP (1999). Physicochemical stability of natural and sweetened frozen passion fruit juice.Braz, Biol. Technol. 42:392396.

Stephen N (2014). Retrieved from http://stephennothingham.w.uk ./beetroot-html.

Suaad SA, Emen AHA (2008). Microbial growth and chemical analysis of bottled fruits and drinks in Riyadh Saud, Arabia Res. J. Microbiology.3:319 - 325 .

Vanhatolo A, Bailey SJ, Blackwell JR, Dimenga FJ, Pavey TG, Wilkerson, DP, Benjamin N, Winyard PG, Jones AM (2010). Acute and chronic effecs of dietary nitrate supplementations on blood pressure and the physiological responses to moderate - intensity and incremental exercise. American J. Physiology Requl.Integr. Comp physiol. 299. R1121 - R1131.

WahuaTAT(1999). Applied Statistics for Scientific Studies.African Link Press, Aba, Nigeria.

Webb AJ, Patel N, Loukogeorgakiss, Okorie M, Aboudz, Misra S, Rashid R, Miall P, Deanfield J, Benjamin N, MacAkister R, Hobbs AJ, Ahluwalia A (2008). Acute blood pressure lowery, vasoprotectine and antiplatelet properties of dietary nitrate via bioconversion to nitrate. Hypertension. 51, $784-790$.

Wilie LJ, Kelly J, Bailey SJ, Blackwell (Jr.), Skiba PF, Winyard PG, Jeukendruphe, Vatiuatato A, Jones AM (2012). Beetroot juice and exercise: pharmacodynamic and dose-response. J. of Applied physiology. 115(3) 325 -336.Doi:10.1152/japp/physio/.00372.2013 